\title{
Prenatal follow-up of Haitian and Brazilian women in Mato Grosso
}

Delma Riane Rebouças Batista 1

Silvia Angela Gugelmin 2

Ana Paula Muraro 3

\footnotetext{
1,2 Departamento de Saúde Coletiva. Instituto de Saúde Coletiva. Universidade Federal de Mato Grosso. Cuiaba, MT, Brasil.

3 Programa de Pós-graduação em Nutrição, Alimentos e Metabolismo. Faculdade de Nutrição. Universidade Federal de Mato Grosso. Cuiaba, MT, Brasil. Av. Fernando

Correa da Costa, 2367. Boa Esperança. Cuiabá, MT, Brasil. CEP: 78.060-900. E-mail: muraroap@gmail.com
}

\begin{abstract}
Objectives: to analyze the prenatal follow-up performed by pregnant women in Haiti and Brazil in the state of Mato Grosso.

Methods: a cross-sectional study of secondary database, with analysis of SINASC birth records in Mato Grosso between 2013 and 2015, of Brazilian children, born from both Brazilian and Haitian mothers. Variables related to the identification of the newborn and the woman, maternal data on gestational history, including information on prenatal follow-up of the last gestation were evaluated, besides the birth characteristics.

Results: 167,820 live births were registered in the state in the period, of which 139 $(0.08 \%)$ were children of Haitian women. Haitian mothers were older, however with lower schooling when compared to Brazilian mothers. The proportion of mothers of Haitian nationality who had at least 6 prenatal consultations was lower, and the proportion of vaginal births was higher, when compared to Brazilian women. The prevalence of low birth weight among live births of Haitian mothers was also higher.

Conclusions: the results of this study point to the need to understand these differences, since some indicators have distanced from those advocated by WHO. These findings may contribute to the public policies development aimed at this population.

Key words Emigration and immigration, Prenatal Care, Childbirth, Health policy, planning and management
\end{abstract}




\section{Introduction}

Several social and economic factors in Haiti influence the migratory process of its population, which began at the end of the 19th century, with a large flow of Haitians leaving for the Dominican Republic and Cuba, in order to work on sugar production in these countries. ${ }^{1}$ Brazil began to be considered as one of the main destinations since 2010, when an increase was observed in the number of Haitian immigrants who sought in the country the means to a better life. ${ }^{2}$ This migratory movement has already involved thousands of Haitians, being this the main nationality among foreign workers currently registered in Brazil. 3

The state of Mato Grosso has presented, since 2012, a progressive increase in the number of Haitian immigrants, 3 among them, women of reproductive age which, in turn, may have caused the increase in the number of births of Haitian women's children by the process of family reunification. This fact points to the need for closer attention to the living and health conditions of this segment of the population.

When dealing with maternal and child health, there are several particularities that can influence the gestational conditions, delivery and puerperium of each woman, from biological aspects to socioeconomic and psychic factors. In this sense, prenatal consultation is an important ally in maternal and neonatal health care, since several health problems, both of the pregnant woman and the child, can be prevented, identified and/or treated by professionals during the gestational period. 4

The early initiation of prenatal care is very important for adequate care, and the first consultation is recommended until the third gestational month. The number of prenatal consultations to be performed, also recommended by the World Health Organization (WHO), should be equal to or higher than six, guaranteeing the quality of these consultations. ${ }^{4}$

Almeida et al. 5 verified that foreign mothers started the prenatal follow-up later and had fewer consultations when compared to those of Portuguese nationality. In Brazil, a study on access to health care by Bolivian immigrant women and children reveals that this population positively faces access to health in the country where they live, when compared to their country of origin. 6

In 2012 , in Haiti, $67.3 \%$ of pregnant women performed at least four prenatal consultations, ${ }^{7}$ and in previous years (2005), there was a difference in coverage and number of consultations among preg- nant women living in rural and urban areas, of $77.2 \%$ and $85.8 \%$, respectively. The averages of prenatal consultations were 3.8 for rural residents and 5.1 for those residing in the urban area. ${ }^{8}$ These characteristics may be due to cultural issues as well as to the conditions offered by the Haitian health system.

Despite the growing trend in the number of births within Haitian women in Brazil, no studies were found to evaluate prenatal care offered to this population. In this sense, the present study aims to analyze the prenatal care performed by pregnant women living in the state of Mato Grosso, in order to encourage the planning of more specific actions to approach this population.

\section{Methods}

A cross-sectional study was performed, based on data available in the Live Birth Information System (Sinasc). The records of live births of Brazilian women and children of women of Haitian nationality in Mato Grosso in the years of 2013, 2014 and 2015 were considered. The data used were provided by the State Department of Health of Mato Grosso.

Sinasc was implemented by the Ministry of Health in 1990, which was based on the data obtained from the Live Births Declaration Registry (DN - Portuguese acronym), composed of eight blocks of information. The information collected is sent hierarchically to the Municipal and State Health Secretariat and, finally, provided to the Ministry of Health to feed the Information System of the Unified Health System (SUS). 9

Data were collected from three of the eight information blocks of the DN, including: newborn identification, data on the mother, pregnancy and delivery. Haitian mothers' data were compared with Brazilian mothers' data, and this information was identified by the field "naturalness of the mother" in DN.

Regarding the information regarding the maternal data, the following were analyzed: mother's age range (less than 25 years, between 25 and 29 years, and 30 years or more); mother's marital status (single, married, common-law marriage or others); maternal schooling (5 to 11 years of study, and 12 years or more of study); number of previous pregnancies (none, one to two, three or more); number of children born alive (none, one to two, three or more); number of children born dead (none, one or more).

For the prenatal data analysis, the number of prenatal consultations was classified into two categories ( 6 or more and less than 6 visits), and the period of initiation of consultations was classified up 
to the third month of gestation or after the 3 rd month. Both variables considered WHO's recommendation. 10

Concerning the child's birth data, gestational age was classified as preterm (up to 36 weeks), term (between 37 and 41 weeks) and post-term (42 weeks or more), 4 being the latter two categories due to the low number of births recorded as post-term when referred to the children of Haitian mothers. The type of delivery (vaginal or cesarean section) and birth weight, classified according to WHO10 in adequate birth weight ( $\geq 2500$ grams) and low birth weight ( $<2500$ grams) were also evaluated. The Apgar index is related to the degree of anoxia that the newborn presents after birth and in the present study only the Apgar of the first minute of life was evaluated. Apgar between 8 and 10 is considered normal, 7 mild anoxia, 4 to 6 moderate anoxia and zero to 3 severe anoxia. 11 In this study, the Apgar score was classified as up to 7 (some degree of anoxia) and between 8 and 10 .

To test the differences among the proportions, the chi-square test was applied, and the analyses were performed using SPSS software, version 17.

This study is part of the research project approved by the Ethics Committee of Júlio Muller Hospital of the Federal University of Mato Grosso (No. 29120414.0.0000.5541). The research was funded by the Foundation for Research Support of the State of Mato Grosso (FAPEMAT - Process $155709 / 2014)$ and the National Council for Scientific and Technological Development (CNPq Process 445842 / 2014-7).

\section{Results}

In Mato Grosso, 167,820 live births were registered between 2013 and $2015(2013=53,573 ; 2014=$ $57,083 ; 2015=57,164)$. The incompleteness of the mother's natural information (country, state or municipality) was only $1.32 \%$ (2,220 births). Thus, 165,600 birth records were selected initially, of which 765 were children of foreign mothers $(0,50 \%)$. Among the records of mothers of other nationalities, the main countries of origin were Bolivia ( $\mathrm{n}=396,0.2 \%)$, Paraguay $(\mathrm{n}=139,0.08 \%)$ and Haiti ( $\mathrm{n}=139 ; 0.08 \%)$.

In the data analysis, the characteristics of the live births of Brazilian and Haitian mothers were compared, making a total of 164,974 evaluated births. Haitian mothers had a higher age group in the delivery period, however with lower schooling when compared to Brazilian mothers (Table 1). The Haitian women's reproductive history (gestation number, number of live births and dead children) did not differ from Brazilian women (Table 1). Regarding prenatal and delivery, when compared to Brazilian mothers, there was a lower proportion of Haitian mothers with at least six prenatal consultations, a higher proportion of vaginal deliveries, and a higher prevalence of live births with low birth weight (Table 2). All deliveries of Haitian women evaluated occurred in a hospital environment (data not shown in the table).

When analyzing the distribution of low birth weight (Table 3), a higher prevalence was observed among mothers with a higher age group, lower education, first gestation, with less than 6 antenatal visits and Apgar in the first minute up to 7.

\section{Discussion}

The results of this study show that some important indicators have distanced themselves from those recommended by WHO among mothers of Haitian nationality, such as the number of prenatal consultations and the percentage of children with low birth weight. However, the proportion of vaginal deliveries among Haitians was higher when compared to Brazilian women, which may be related to both cultural characteristics and socioeconomic factors of this population group.

All the prenatal care provided during the gestational period can influence the type of delivery indicated and offered in each case. Currently, it is estimated that $40.5 \%$ of all births in Latin America and the Caribbean occurred through surgical birth, with South America being the subregion with the highest cesarean rates in the world, with $42.9 \% .12$ As expected, therefore, data evaluated in this study present indices that exceed WHO's recommendation, ${ }^{4}$ both in Brazilian and Haitian women, but show a statistically significant difference between the groups, with a lower proportion of cesarean sections among Haitian women. This fact may be related to the socioeconomic profile of immigrants, since in Brazil a positive association is observed between the level of maternal schooling and birth by the surgical route, 13 with the majority of Haitian women residing in the country having low levels of schooling and having a socioeconomic status considered vulnerable. ${ }^{14,15}$ It is also worth mentioning the possible influence of skin color on the prenatal care offered and on the route of delivery. According to the Ministry of Health, 16 the proportion of prenatal consultations performed by women who declared white skin color in 2013 was higher when compared to the black and brown categories and the agency 
Maternal characteristics according to mother's nationality. Mato Grosso, 2013 to 2015.

\begin{tabular}{|c|c|c|c|c|c|c|c|}
\hline & \multicolumn{2}{|c|}{ General } & \multicolumn{2}{|c|}{$\begin{array}{c}\text { Children of } \\
\text { Haitian }\end{array}$} & \multicolumn{2}{|c|}{$\begin{array}{l}\text { Children of } \\
\text { Brazilian }\end{array}$} & \multirow[t]{2}{*}{ pa } \\
\hline & $\mathrm{n}$ & $\%$ & $\mathrm{n}$ & $\%$ & $\mathrm{n}$ & $\%$ & \\
\hline Age group of the mother (years) & & & & & & & $<0.001$ \\
\hline$<25$ & 79.303 & 48.1 & 29 & 20.9 & 79.274 & 48.1 & \\
\hline 25 to 29 & 41.862 & 25.4 & 61 & 43.9 & 41.801 & 25.4 & \\
\hline$\geq 30$ & 43.809 & 26.6 & 49 & 35.3 & 43.760 & 26.5 & \\
\hline Marital status of mother & & & & & & & not applicable \\
\hline Single & 47.293 & 28.8 & 47 & 33.8 & 47.246 & 28.8 & \\
\hline Married & 46.637 & 28.4 & 26 & 18.7 & 46.611 & 28.4 & \\
\hline Stable union & 68.204 & 41.5 & 66 & 47.5 & 68.138 & 41.5 & \\
\hline Others & 2.289 & 1.4 & - & - & 2.289 & 1.4 & \\
\hline Mother's education (years)b & & & & & & & $<0.001$ \\
\hline$<5$ & 7.990 & 4.9 & 16 & 11.9 & 7.974 & 4.9 & \\
\hline 5 to 11 & 86.179 & 52.6 & 75 & 56.0 & 86.104 & 52.6 & \\
\hline$\geq 12$ & 69.608 & 42.5 & 43 & 32.1 & 69.565 & 42.5 & \\
\hline Previous pregnanciesb & & & & & & & 0.440 \\
\hline None & 53319 & 34.5 & 41 & 32.5 & 53278 & 34.5 & \\
\hline $1-2$ & 76879 & 49.8 & 60 & 47.6 & 76819 & 49.8 & \\
\hline$\geq 3$ & 24251 & 15.7 & 25 & 19.8 & 24226 & 15.7 & \\
\hline Number of children born aliveb & & & & & & & 0.639 \\
\hline None & 59.504 & 38.7 & 44 & 34.9 & 59.460 & 38.7 & \\
\hline $1-2$ & 77.380 & 50.3 & 66 & 52.4 & 77.314 & 50.3 & \\
\hline$\geq 3$ & 16.939 & 11.0 & 16 & 12.7 & 16.923 & 11.0 & \\
\hline Number of children deadb & & & & & & & 0.292 \\
\hline None & 121.415 & 81.4 & 103 & 85.1 & 121.312 & 81.4 & \\
\hline$\geq 1$ & 27.741 & 18.6 & 18 & 14.9 & 27.723 & 18.6 & \\
\hline
\end{tabular}

aChi-square test; bVariable with incomplete information. 
Characteristics of prenatal care. Birth and conditions at birth, according to the mother's nationality. Mato Grosso. 2013 to 2015.

\begin{tabular}{ccc} 
General & $\begin{array}{c}\text { Children of } \\
\text { Haitian }\end{array}$ & $\begin{array}{c}\text { Children of } \\
\text { Brazilian }\end{array}$ \\
\hline
\end{tabular}

$\begin{array}{lllll}\mathrm{n} & \% & \mathrm{n} & \% & \mathrm{n}\end{array}$

\begin{tabular}{|c|c|c|c|c|c|c|c|}
\hline Prenatal onsetb & & & & & & & 0.112 \\
\hline Up to 3 rd month of gestation & 127.222 & 79.8 & 95 & 74.2 & 127.127 & 79.9 & \\
\hline After the 3rd month & 32.109 & 20.2 & 33 & 25.8 & 32.076 & 20.1 & \\
\hline Number of prenatal visitsb & & & & & & & 0.013 \\
\hline$<6$ & 31.374 & 19.3 & 37 & 27.8 & 31.337 & 19.3 & \\
\hline$\geq 6$ & 130.990 & 80.7 & 96 & 72.2 & 130.894 & 80.7 & \\
\hline Gestacional ageb & & & & & & & 0,569 \\
\hline Pre-term & 17.513 & 10.9 & 17 & 12.4 & 17.496 & 10.9 & \\
\hline Term or Post-term & 143.262 & 89.1 & 120 & 87.6 & 143.142 & 89.1 & \\
\hline Type of deliveryb & & & & & & & $<0.001$ \\
\hline Vaginal & 64.011 & 38.8 & 81 & 58.3 & 63.930 & 38.8 & \\
\hline Caesarean & 100.819 & 61.2 & 58 & 41.7 & 100.761 & 61.2 & \\
\hline Sex of the childb & & & & & & & 0.476 \\
\hline Male & 84.473 & 51.2 & 67 & 48.2 & 84.406 & 51.2 & \\
\hline Female & 80.440 & 48.8 & 72 & 51.8 & 80.368 & 48.8 & \\
\hline Weight at birth (grams)b & & & & & & & $<0.001$ \\
\hline$\geq 2500$ & 152.387 & 92.4 & 115 & 82.7 & 152.272 & 92.4 & \\
\hline$<2500$ & 12.475 & 7.6 & 24 & 17.3 & 12.451 & 7.6 & \\
\hline Apgar 1b & & & & & & & 0.056 \\
\hline $8-10$ & 145.978 & 89.2 & 117 & 84.2 & 145.861 & 89.2 & \\
\hline Up to 7 & 17.660 & 10.8 & 22 & 15.8 & 17.638 & 10.8 & \\
\hline
\end{tabular}

aChi-square test; bVariable with incomplete information. c Number of post-term births of children of Haitian mothers less than 5 . 
Distribution of low birth weight $(<2500 \mathrm{~g})$ by socio-demographic characteristics and related to prenatal and delivery, according to mother's nationality. Mato Grosso. 2013 to 2015.

\begin{tabular}{|c|c|c|c|c|c|c|}
\hline & \multicolumn{6}{|c|}{ Stratified by nationality } \\
\hline & \multicolumn{2}{|c|}{ General } & \multicolumn{2}{|c|}{$\begin{array}{l}\text { Children of } \\
\text { Haitian }\end{array}$} & \multicolumn{2}{|c|}{$\begin{array}{l}\text { Children of } \\
\text { Brazilian }\end{array}$} \\
\hline & $\mathrm{n}$ & $\%$ & $\mathrm{n}$ & $\%$ & $\mathrm{n}$ & $\%$ \\
\hline \multicolumn{7}{|l|}{ Age group of the mother (years) } \\
\hline$<25$ & 5816 & 7.3 & 4 & 13.8 & 5812 & 7.3 \\
\hline 25 to 29 & 2939 & 7.0 & 8 & 13.1 & 2931 & 7.0 \\
\hline$\geq 30$ & 3726 & 8.5 & 12 & 24.5 & 3714 & 8.5 \\
\hline pa & \multicolumn{2}{|c|}{$<0.01$} & \multicolumn{2}{|c|}{-} & \multicolumn{2}{|c|}{$<0.01$} \\
\hline \multicolumn{7}{|l|}{ Mother's education (years)b } \\
\hline$<5$ & 658 & 8.3 & 3 & 18.8 & 655 & 8.3 \\
\hline 5 to 11 & 6378 & 7.4 & 15 & 20.0 & 6363 & 7.4 \\
\hline$\geq 12$ & 5354 & 7.7 & 5 & 11.6 & 5349 & 7.7 \\
\hline$p^{a}$ & \multicolumn{2}{|c|}{$<0.01$} & \multicolumn{2}{|c|}{ - } & \multicolumn{2}{|c|}{$<0.01$} \\
\hline \multicolumn{7}{|l|}{ Previous pregnanciesb } \\
\hline None & 4517 & 8.5 & 7 & 17.1 & 4510 & 8.5 \\
\hline $1-2$ & 4990 & 6.5 & 12 & 20.0 & 4978 & 6.5 \\
\hline$\geq 3$ & 1948 & 8.0 & 3 & 12.0 & 1945 & 8.0 \\
\hline pa & \multicolumn{2}{|c|}{$<0.01$} & \multicolumn{2}{|c|}{-} & \multicolumn{2}{|c|}{$<0.01$} \\
\hline \multicolumn{7}{|l|}{ Prenatal onsetb } \\
\hline Up to 3rd month of gestation & 9383 & 7.4 & 15 & 15.8 & 9368 & 7.4 \\
\hline After the 3rd month & 2438 & 7.6 & 4 & 14.8 & 2434 & 7.6 \\
\hline pa & \multicolumn{2}{|c|}{0.17} & \multicolumn{2}{|c|}{ - } & \multicolumn{2}{|c|}{0.17} \\
\hline \multicolumn{7}{|l|}{ Number of prenatal visitsb } \\
\hline$<6$ & 3918 & 12.5 & 10 & 27.0 & 3908 & 12.5 \\
\hline$\geq 6$ & 8222 & 6.3 & 11 & 11.5 & 8211 & 6.3 \\
\hline pa & \multicolumn{2}{|c|}{$<0.01$} & \multicolumn{2}{|c|}{0.03} & \multicolumn{2}{|c|}{$<0.01$} \\
\hline \multicolumn{7}{|l|}{ Gestacional age ${ }^{b}$} \\
\hline Pre-term & 4937 & 3.4 & 11 & 9.2 & 4926 & 3.4 \\
\hline Term or Post-termc & 7216 & 41.2 & 13 & 76.5 & 7203 & 41.2 \\
\hline$p^{a}$ & \multicolumn{2}{|c|}{$<0.01$} & \multicolumn{2}{|c|}{$<0.01$} & & \\
\hline Type of deliveryb & & & & & & \\
\hline Vaginal & 4893 & 7.6 & 11 & 13.6 & 4882 & 7.6 \\
\hline Caesarean & 7578 & 7.5 & 13 & 22.4 & 7565 & 7.5 \\
\hline pa & & & & & & \\
\hline Apgar 1b & & & & & & \\
\hline $8-10$ & 8787 & 6.0 & 16 & 13.7 & 8771 & 6.0 \\
\hline Up to 7 & 3571 & 20.2 & 8 & 36.4 & 3653 & 20.2 \\
\hline pa & & & & & & \\
\hline
\end{tabular}

a Chi-square test; bVariable with incomplete information; cNumber of post-term births of children of Haitian mothers less than 5. 
also points out a trend in the increase of cesarean sections in the whole country, but especially in the South, Southeast and Midwest regions, and also among women aged between 20 and 39 years old, with a higher grade of schooling and white skin color.

The number of immigrant women spread throughout the world has increased, making it necessary to pay more attention to this population group, since they have cultural, psychosocial and biological specificities. 17 According to Kobetz et al., 18 the greatest difficulties of access to health faced by immigrant Haitian women in Miami, regarding health services, were related to structural obstacles, such as financial problems related to treatment costs, problems (or irregularities) in immigrant status, communication difficulties (language) and lack of information on issues of health and rights.

Mascaro, 19 on the other hand, described the difficulties of a health service in São Paulo on developing actions that facilitate the access of Bolivian women migrants. In addition to the language barrier and cultural differences, the following were listed as barriers on the establishment of links with these women: service hours, discrimination on the part of professionals, gender inequality and domestic violence. In this sense, the team sought overcoming and welcoming strategies in order to get through these barriers and offer quality care services. In Cuiabá, capital of the state of Mato Grosso, a study of the socioeconomic and health profile of Haitian immigrants showed a higher prevalence of health services utilization among women, 20 which the authors evaluated as being associated, at least in part, to care related to gestation and delivery.

Essential care for immigrant women refers to prenatal care, as it is already recognized in the literature that several factors influence maternal and neonatal health care and conditions, including: maternal age, mother's education, number of previous pregnancies, number of children and type of childbirth. ${ }^{21}$ It should be remembered that among immigrants there are other factors involved in health care of women and children, such as language barriers, discrimination and irregularities in documentation, 18,19 which indicate an inequality in the access to health service.

It is also necessary to point out possible deficiencies related to the Brazilian health system, such as areas that are not covered by basic health care teams, incomplete teams in basic health care, lack of preparation of staff to attend specific populations, management problems, and the application of funds directed towards health, among other factors that may have a direct influence on the indicators of prenatal care and childbirth, both for Brazilian women and immigrants.

It is essential that the pregnant woman initiates the prenatal follow-up in the first trimester in order to identify possible complications inherent to that period, as well as to receive relevant information that can minimize risks during pregnancy. Concomitant with the early initiation of this follow-up, WHO recommends that at least six prenatal consultations should be carried out, thus enabling adequate assistance and follow-up during this period. ${ }^{4}$ Based on the results presented, it can be observed that the number of Brazilian women (80.7\%) who had six or more consultations was superior to the Haitian women $(72.2 \%)$. This difference may be related to the poor understanding of the health network in Brazil, as well as to the Portuguese language, barriers considered common in the adaptation process to a new country. 17 In addition, there are cases in which gestation started before migration process to Brazil, which should be considered in studies with this population.

A study with Bolivian immigrants in São Paulo showed that residence time in Brazil was associated with the use of different health services, especially primary health care, which was more used among those who lived in the country. 6 Therefore, it is essential to promote actions that stimulate the search for prenatal care among Haitian pregnant women, in order to minimize possible impacts on the women's and children's health.

Regarding the age group, when the low birth weight with maternal age was evaluated in the studied population, a higher prevalence was observed among mothers aged 30 years or older, according to the literature. 22 The results also showed a difference in the age of Haitian mothers when compared to the maternal age of Brazilian women, with the majority of Haitians (79.1\%) at the time of delivery being 25 years or older, while $48.7 \%$ of the Brazilian women were of lower age to 25 years. The highest age group of Haitian women is possibly related to the profile of women who tend to migrate to Brazil, as verified by data from the Federal Police between 2010 and 2014, in which the majority of women were between 25 to 39 years. ${ }^{23}$ Likewise, it was estimated in Cuiabá that $78.2 \%$ of the women were between 26 and 45 years of age. 14

The higher prevalence of low birth weight among the children of Haitian women may be related to two situations: inadequate follow-up during the gestational period (consultation number lower than that recommended), due to the difficulty accessing 
services; and the precarious living conditions of migrant women, who usually live in small households, with a greater density of people per room, unemployed. In a study with the Haitian population in Cuiabá, Leão et al., 15 verified that $45.6 \%$ of the women interviewed were unemployed and $41.6 \%$ reported having no income in the month prior to the interview.

Corroborating these hypotheses, in an additional analysis on the association of socio-demographic and prenatal characteristics with low birth weight, a higher prevalence of this outcome was found among mothers with lower educational level and less than six prenatal consultations. It is therefore opportune to understand the relation of these social and economic factors regarding access to health services, since LBW is one of the main risk factors for neonatal death and may influence the child's health in the short and long term. ${ }^{24}$ Among the possible problems resulting from LBW is the delay in achieving adequate weight and length in the first year of life, intercurrences related to respiratory diseases and acute diarrhea, and the need for hospitalization for an average of 11 days in the first year of the child's life. 25

Another important risk factor for infant survival, as well as indicator of the socioeconomic familiar condition, refers to maternal schooling. Low maternal schooling has been related to fetal losses, risk of perinatal mortality, low birth weight and infant malnutrition. For this reason, the Ministry of Health preconizes higher children and maternal healthcare when the mother portrays low schooling. In Brazil, in the year 2010, approximately $35 \%$ of mothers had less than eight years of schooling. 24

The present study highlights the socioeconomic profile of the population analyzed, in which the majority of Brazilian and Haitian women did not reach the conclusion of high school or equivalent schooling, tending to present inadequate socioeconomic conditions and greater social vulnerability. There is, however, a significant percentage difference in this sense, while $11.9 \%$ of the Haitian mothers evaluated in this study had schooling of up to five years of study, only $4.9 \%$ of Brazilians had this level of education, which seems to indicate inequality in the access to education among Haitian women. In Haiti, the educational system maintains, to a certain extent, the separation of elites and poor masses or popular classes, evidenced by the increase in the number of private schools, demonstrating a process of privatization of education. In 2008, approximately $83.0 \%$ of the schools in the country belonged to the private network, making it difficult for the less privileged population to access higher schooling levels. 26

The woman's obstetric history should also be considered, since the number of previous pregnancies, gestational and puerperal complications, type of delivery, among other factors, may directly influence later pregnancies, ${ }^{21}$ as well as the maternal perception about the need for care in this period. The present study presents, in an unprecedented way, that Haitians and Brazilians showed similarity in the number of previous pregnancies.

Finally, the Apgar score is another factor that can be influenced by prenatal care, since care during pregnancy can prevent, identify and/or treat possible problems that influence this variable. The necessary care at birth will vary according to the Apgar score of each child.11 In the present study, the first minute Apgar did not present a significant difference among the groups, with an index below 7, ranging from $10.8 \%$ (in the children of Brazilian mothers) to $15.8 \%$ (in the children of Haitian mothers). Although the statistical analysis does not indicate differences between the nationalities, it is important for the service to know this reality, since the index below 7 refers to children who need quick and effective monitoring and/or care in their first hours of life, in order to ensure their survival with health. Studies show the association of the low Apgar index with precarious socioeconomic conditions 27,28 and inadequate prenatal care. 29

Given the data and discussion, it is observed that, although higher among immigrant women, most of the problems identified in the study are commonly found and discussed among the national population, which may not only be due to immigrant status, but conditions offered by the Brazilian health system. These problems can be aggravated in the immigrant populations, as they commonly face difficulties in the host country, related to socioeconomic inequalities, leading to precarious access to the labor market, housing and education, as well as inadequate environmental conditions. ${ }^{30}$

Among the limitations of this study, the use of secondary source data should be considered, and the information quality related to adequate DN filling and Sinasc feeding should be considered. The Manual Instruction for completing the Birth Declaration ${ }^{9}$ emphasizes the importance of adequately completing all $\mathrm{DN}$ fields in order to ensure the reliability of the obtained data. However, there is still underreporting of Sinasc births, ranging from $75.8 \%$ to $99.5 \%$, and inadequate completion of many variables, such as maternal education, parity and number of prenatal visits. 27 The incompleteness 
of basic DN fields, such as gender of the newborn and type of delivery, was high among the findings of the present study, possibly indicating the lack of attention and importance given to DN by the professional responsible for filling it.

Despite the limitations and criticisms on secondary databases, the findings confirm the literature regarding the difference in prenatal care among Brazilian and Haitian women. It should be noted that the low incompleteness of maternal naturality information in Sinasc (1.32\%) allowed the analysis of the maternal and infant characteristics of the births recorded in the state in the evalauted period However, this information is not available for analysis in other information systems, such as the SIH-SUS (Hospital Information System of SUS) and SIA (Ambulatory Information System), making it impossible to analyze the use of health services by international immigrants.

The present study reveals the importance of the development of studies on immigrants in Brazil, with a deepening of the discussion focused on health

\section{References}

1. Beaninger R, Peres R, Fernandes D, Silva AS, Assis GO, Castro MCG, Cotinguiba MP. (orgs.). Imigração haitiana no Brasil. Jundiaí (SP): Paco Editorial; 2017.

2. Moraes IA, Andrade CAA, Mattos BRB. A imigração haitiana para o Brasil: causas e desafios. Rev Conjuntura Austral. 2013; 4 (20): 95-114.

3. Dutra D, Almeida S, Tonhati T, Palermo G. Os estrangeiros no mercado de trabalho formal brasileiro: Perfil geral na série 2011, 2012 e 2013. Anuário 2015. Cad OBMigra - Rev Migrações Inter. Brasília (DF): OBMigra. 2015; 1 (2): 4881.

4. WHO (World Health Organization). New guidelines on antenatal care for a positive pregnancy experience. Sexual and reproductive health [internet]. Nov. 2016 [acesso em 29/12/2016]. Disponível em: http://www.who.int/reproductivehealth/news/antenatal-care/en/.

5. Almeida LM, Santos CC, Caldas JP, Ayres-de-Campos D, Dias S. Obstetric care in a migrant population with free access to health care. Int J Gynaecol Obstet. 2014; 126 (3): 244-7.

6. Martes ACB, Faleiros SM. Acesso dos imigrantes bolivianos aos serviços públicos de saúde na cidade de São Paulo. Saúde Soc. 2013; 22 (2): 351-64.

7. UNICEF (United Nations Children's Fund). At a glance: Haiti - Statistics. UNICEF [internet]. 2013 [acesso em: 07/11/2017]. Disponível: http://www.unicef.org/infobycountry/haiti_statistics.html\#106.

8. Alexandre PK, Saint-Jean G, Crandall L, Fevrin E. Prenatal care utilization in rural areas and urban areas of Haiti. Rev Panam Salud Publica/Pan Am J Public Health. 2005; 18 (2): 84-92. care for this population group and on the public policies evaluation, considering the vulnerabilities imposed by the migratory situation. Regarding women's and children's health, the socioeconomic characteristics of Haitian women can be highlighted, predominantly with low schooling, as a fact that may influence health care in a country with a health system different from its country of origin.

\section{Acknowledgment}

The State Secretary of Health, specifically to the Superintendency of Health Surveillance for the availability of data analyzed in this study. We also thank the suggestions and criticism of the first versions of this article, received in the discipline of Workshop of Production of Scientific Articles, by Professor Marina Tanaka, from the Graduate Program in Collective Health of the Federal University of Mato Grosso.

9. Brasil. Ministério da Saúde. Secretaria de Vigilância em Saúde. Departamento de Análise de Situação de Saúde. Manual de Instruções para o preenchimento da Declaração de Nascido Vivo. Brasília, DF; 2011.

10. WHO (World Health Organization). Low birthweight. Country, regional and global estimates [internet]. 2004 [acesso em 02/12/2016]. Disponível em: http://apps.who.int /iris/bitstream/10665/43184/1/9280638327.pdf.

11. Santos LM, Pasquini VZ. A importância do Índice de Apgar. Rev Enferm UNISA. 2009; 10 (1): 39-43.

12. Betrán AP, Ye J, Moller A-B, Zhang J, Gülmezoglu AM, Torloni MR. The Increasing Trend in Caesarean Section Rates: Global, Regional and National Estimates: 19902014. PLoS ONE. 2016; 11 (2): e0148343.

13. Rattner D, Moura EC. Nascimentos no Brasil: associação do tipo de parto com variáveis temporais e sociodemográficas. Rev Bras Saúde Matern Infant. 2016; 16 (1): 39-47.

14. Borges FT, Muraro AP, Leão LHC, Carvalho LA, Siqueira CEG. Socioeconomic and health profile of Haitian Immigrants in a Brazilian Amazon State. J Immigr Minor Health. 2018; 1-7.

15. Leão LHC, Muraro AP, Palos CC, Martins MAC, Borges FT. Migração internacional, saúde e trabalho: uma análise sobre os haitianos em Mato Grosso, Brasil. Cad Saúde Pública. 2017; 33 (7): e0018181.

16. Brasil. Ministério da Saúde. Secretaria de Vigilância em Saúde. Departamento de Análise de Situação em Saúde. Saúde Brasil 2013: uma análise da situação de saúde e das doenças transmissíveis relacionadas à pobreza / Ministério da Saúde, Secretaria de Vigilância em Saúde, Departamento de Análise de Situação em Saúde. - Brasília, DF; 2014. 
17. Topa J, Neves S, Nogueira C. Imigração e saúde: a (in)acessibilidade das mulheres imigrantes aos cuidados de saúde. Saúde Soc. 2013; 22 (2): 328-41.

18. Kobetz E, Menard J, Barton B, Maldonado JC, Diem J, Auguste PD, Pierre L. Barriers to Breast Cancer Screening Among Haitian Immigrant Women in Little Haiti, Miami. J Immigr Minor Health. 2010; 12 (4): 520-6.

19. Mascaro LDM. Imigrantes bolivianos: abordagem de direitos humanos ao direito ao desenvolvimento. In: Mota A, Marinho MGSMC, Silveira C. (Org.) Saúde e história de migrantes e imigrantes. Direitos, Instituições e Circularidades. São Paulo: USP/ UFABC; 2014. p.199-225.

20. Alves JFS, Martins MAC, Borges FT, Silveira C, Muraro AP. Utilização de serviços de saúde por imigrantes haitianos na grande Cuiabá, Mato Grosso. Ciênc Saúde Coletiva. 2018. Disponível em: http://www.cienciaesaudecoletiva.com.br/artigos/utilizacao-de-servicos-desaude-por-imigrantes-haitianos-na-grande-cuiaba-matogrosso/16786?id=16786.

21. Rosa CQ, Silveira DS, Costa JSD. Fatores associados à não realização de pré-natal em município de grande porte. Rev Saúde Pública. 2014; 48 (6): 977-84.

22. Montan S. Increased risk in the elderly parturiente. Curr Opin Obstet Gynecol. 2007; 19 (2): 110-2.

23. Gravena AAF, Paula MG, Marcon SS, Carvalho MDB, Pelloso SM. Idade materna e fatores associados a resultados perinatais. Acta Paul Enferm. 2013; 26 (2): 130-5.

24. Brasil. Ministério da Saúde. Secretaria de Atenção à Saúde. Departamento de Ações Programáticas Estratégicas. Atenção à saúde do recém-nascido: guia para os profissionais de saúde. 2 ed. Brasília, DF; 2012b.
25. Martins EF, Rezende EM, Almeida MCM, Lana FCF. Mortalidade perinatal e desigualdades sócioespaciais. Rev Lat Am Enfermagem. 2013; 21 (5): 1-9.

26. Joint LA. Sistema educacional e desigualdades sociais no Haiti: o caso das escolas católicas. Pro-Posições. 2008; 19 (56): 181-191.

27. Chrisman JR, Mattos IE, Koifman RJ, Koifman S, Boccolini PMM, Meyer A. Prevalência de muito baixo peso ao nascer, malformação e baixo índice de Apgar entre os recém nascidos no Brasil de acordo com a residência materna urbana ou rural no nascimento. J Obstet Gynaecol. Res. 2016; 42 (5): 496-504.

28. Kilsztajn S, Lopes ES, Carmo MSN, Reyes AMA. Vitalidade do recém-nascido por tipo de parto no Estado de São Paulo, Brasil. Cad Saúde Pública. 2007; 23 (8): 188692.

29. Ferrari RAP, Bertolozzi MR, Dalmas JC, Girotto E. Associação entre assistência pré-natal e mortes neonatais, 2000-2009, Londrina-PR. Rev Bras Enferm. 2014; 67 (3): 354-9.

30. Granada D, Carreno I, Ramos N, Ramos MCP. Discutir saúde e imigração no contexto atual de intensa mobilidade urbana [internet]. Dossiê. Interface (Botucatu). 2017; 21 (61): 285-96.

Received on September 14, 2017

Final version presented on March 9, 2018

Approved on April 2, 2018 